\title{
Antifertility effects of Solanum xanthocarpum seeds on female albino rats
}

\author{
S.P. Singh and Shiv Pratap Singh* \\ Reproductive Biology Cell, Department of Zoology, D.B.S. (P.G.) College, Dehradun - 248001 (Uttarakhand), INDIA \\ *Corresponding author. E-mail: drshivpalsingh49@yahoo.com \\ Received:February 26, 2013; Revised received:M arch 29, 2013;Accepted:A pril 19, 2013
}

Abstract: The effect of Solanum xanthocarpum seed powder as aqueous suspension on genital organs and fertility of female albino rats was studied at doses of $50,100 \& 150 \mathrm{mg} / \mathrm{kg} /$ day for 30 days. The genital organ weight of albino rats was reduced significantly $(P<0.05)$ after the treatment at 100 and $150 \mathrm{mg} / \mathrm{kg}$ doses of seed powder of $S$. xanthocarpum.for 30 days. The higher doses caused histopathological changes in the ovary and uterus leading to $100 \%$ control of fertility as no implants were recorded in treated female rats on the day 10th of pregnancy.

Keywords: Contraception, Fertility control, Genital organs, Herbal drugs, Solanum xanthocarpum

\section{INTRODUCTION}

Global search on antifertility agents is going on to tackle the problem of "Population Explosion". Many hormonal preparations are available for the purpose but they are not free from side effects. Hence, the search for suitable product from indigenous medicinal plants is proposed, which could be effectively used in place of "Pill".

Indian medicinal plants associated with antifertility property are numerous. They are enlisted under the possible antifertility plants (Chaudhury, 1966 and Farnsworth et al., 1975; Aswal et al., 1984; Sharma et al., 2003; Pokharkar et al., 2010; Jain and Bharathi, 2011). Solanum xanthocarpum Linn. (Family Solanaceae) is one of them. This plant is known as Kateli or Kantkari. The seeds of this plant are considered as a local contraceptive by tribals of India. The powdered seeds and steroidal fraction, Solasodine (Dixit \& Gupta, 1982) of this plant was reported to interfere with spermatogenesis of Indian dog (C. familiaris). Rao (1986, 88) reported antifertility effects in male albino rats. Antifertility study of this plant in female albino rat is lacking. On the basis of above information, the experimental work was done to find out the antifertility effects of seeds of Solanum xanthocarpum on female albino rats (Rattus norvegicus) .

\section{MATERIALS AND METHODS}

The fresh, air dried, powdered seeds filtered through muslin cloth were used at 50,100 and $150 \mathrm{mg} / \mathrm{kg}$ doses. Each dose alongwith $05 \mathrm{mg}$. gum acacia powder was suspended in distilled water. The volume was adjusted in such way that $01 \mathrm{ml}$. of suspension corresponded to each dose.

Adult, cyclic female albino rats ( 150 - $180 \mathrm{~g}$.) were divided into 08 groups each with 05 animals. They were maintained under uniform laboratory conditions with free access of food (Hindustan Lever) and tap water. The seed powder as aqueous solution was administered orally by an intragastric catheter. The I and II groups served as control in which $01 \mathrm{ml}$. of gum acacia $(05 \mathrm{mg} / \mathrm{ml})$ was administered. In III, IV and V groups 50, 100 and $150 \mathrm{mg}$. $\mathrm{kg}$ doses were administered to each rat respectively for 30 days. Similarly, VI, VII and VIII groups received the same doses respectively for 30 days. Before the start of experiment, the body weight of each rat was recorded. On day 31 st, the rats of group I, III, IV and V were weighed and sacrificed.

The ovaries and uterii were dissected out, freed from surrounding tissues, blotted on filter paper and weighed quickly on a semi microbalance. For histopathological studies, the ovaries and uterii were fixed in Bouin's fluid and dehydrated, The paraffin sections of tissues were cut at 6 um. and stained with Ehrlich's haemotoxylin and eosin.

\section{RESULTS}

Effects on body and genital organ weight: Table 1 displays the changes in body and genital organ weight of the rats. The rats of control group did not show any change in body weight and genital organ weight. It was maintained throughout the experimental period. No effect on body weight was observed at any dose of seed powder administered to albino rats. However, the genital organ weight was reduced significantly $(\mathrm{P}<0.05)$ after the treatment at 100 and $150 \mathrm{mg} / \mathrm{kg}$ doses of seed powder for 30 days.

E ffect on histol ogy of genital organ:

Ovaries: The cellular organization of the ovaries of control rats presented normal features as evidenced by presence of all types of follicles, few atretic follicles, 
corpora lutea and normal vascularity in compact stroma. The germinal epithelium was intact (Fig. 1). The dose 50 $\mathrm{mg} / \mathrm{kg}$ for 30 days of administration caused no deleterious effect on ovarian tissues whereas $100 \mathrm{mg} / \mathrm{kg}$ dose within 30 days adversely affected the ovarian structure. Large number of developing as well as mature follicles underwent atresia. Some developing follicles showed lysis of their ova. The stroma was compact with poor vascularity (Fig. 2).

The dose $150 \mathrm{mg} / \mathrm{kg}$ appeared highly effective to cause degenerative changes in the ovary. The administration of this dose for 30 days caused severe damage to cellular organization. Even the large antric follicles underwent atresia and nuclear degeneration. The stroma became fibrotic with poor vasculatiry. The germinal epithelium was atrophied and devoid of primordial oocytes (Fig. 3). Uterii: The uterine histology of the control rats presented normal structure. The endometrium was provided with large epithelial cells having basal and middle nuclei. The uterine glands were numerous, irregular and tortuous. The uterine lumen was highly distended and loose stroma with normal vascularity (Fig. 4). The dose $50 \mathrm{mg} / \mathrm{kg}$ for 30 days did not alter the endometrial height and uterine lumen. The uterine glands were irregular and tortuous. The stroma and vascularity appeared normal. At the dose $100 \mathrm{mg} / \mathrm{kg}$, endometrial height appeared normal. No effect was noticed on musculature, stroma and vascularity. The uterine lumen was reduced significantly. Lack of uterine glands were also noted (Fig. 5). The administration of $150 \mathrm{mg} / \mathrm{kg}$ for 30 days caused great reduction in endometrial height. The uterine glands were shrunken. In the compact stroma, the vascularity was poor. The musculature was also affected (Fig. 6).

Effect on fertility: Table 2 shows the effect of $S$. xanthocarpum seed on fertility of treated female rats and the control group of rats. All rats became pregnant and showed good number of implants. Treated with $50 \mathrm{mg} / \mathrm{kg}$ dose, only $20 \%$ of rats showed pregnancy and reduction of implants. The doses 100 and $150 \mathrm{mg} / \mathrm{kg}$ showed 100\% antifertility activity and no implants were recorded in the horns of uterii of these rats on 10th day of pregnancy.

\section{DISCUSSION}

In the present study, no significant reduction in the weight of body was observed after 30 days of administration of seed powder S. xanthocarpum. A significant reduction in genital organ weight was noticed at 100 and $150 \mathrm{mg} / \mathrm{kgs}$ doses. The results noticed in the present study on histopathology of genital organs are comparable to the studies made by Chakraborti et al. (1968) when the female rats were fed with green leaves of A. odoratissimus Linn. Dixit (1977) reported the follicular degeneration and uterine dysfunction by daily administration (25 days) of M alva viscus conzattii flower extract. Follicular atresia and other changes were reported by Kholkute and Udupa (1974) and Kholkute et al. (1976) following the treatment of extract of Hibiscus rosa sinensis Linn. Flower.The histological changes in the uterii were reported by (Prakash, 1979) on administering the extracts of Embelia ribes Burm. Seeds in albino female rats. The present observations are in agreement with Munshi and Rao (1972) who had reported the effects on endometrial glands, musculature and uterine lumen in female rats after the application of an indigenous plant preparation ROC 101. Lal and Udupa (1993) also reported

Table 1. Effect of S. xanthocarpum seed on body weight and genital organ weight of female albino rats treated for 30 days at different doses ( $\mathrm{mg} / \mathrm{kg} / \mathrm{day}) .05$ rats were included in each group. Values are mean \pm S.E.

\begin{tabular}{|c|c|c|c|c|c|}
\hline \multirow[t]{2}{*}{ Treatment } & \multirow{2}{*}{$\begin{array}{c}\text { Doses } \\
(\mathrm{mg} / \mathrm{kg})\end{array}$} & \multicolumn{2}{|c|}{ Body weight (g) } & \multicolumn{2}{|c|}{ G enital organ wt. (mg) } \\
\hline & & Initial & Final & Ovaries & Uterii \\
\hline Control & Vehicle & $159.00 \pm 0.71$ & $183.80 \pm 0.45$ & $39.40 \pm 0.92$ & $107.00 \pm 1.12$ \\
\hline S. xanthocarpum seed & 50 & $157.00 \pm 0.84$ & $170.20 \pm 2.24$ & $35.90 \pm 0.80$ & $102.50 \pm 0.20$ \\
\hline S. xanthocarpum seed & 100 & $160.60 \pm 2.15$ & $165.00 \pm 211$ & $27.50 \pm 0.40^{*}$ & $84.10 \pm 40.70^{*}$ \\
\hline S. xanthocarpum seed & 150 & $157.10 \pm 489$ & $163.40 \pm 2.16$ & $26.00 \pm 0.30 *$ & $61.20 \pm 0.20 *$ \\
\hline
\end{tabular}

*Significance: $\mathrm{P}<0.05$

Table 2. Antifertility activity of S. xanthocarpum seed in female albino rats. Values are mean \pm S.E.

\begin{tabular}{|c|c|c|c|c|c|}
\hline \multirow[t]{2}{*}{ Treatment/ Group } & \multirow{2}{*}{$\begin{array}{c}\text { Doses } \\
(\mathrm{mg} / \mathrm{kg})\end{array}$} & \multicolumn{2}{|c|}{ Number of rats } & \multirow{2}{*}{$\begin{array}{c}\% \text { Antifertility } \\
\text { activity }\end{array}$} & \multirow{2}{*}{$\begin{array}{c}\text { Number of } \\
\text { implantations } \\
\text { M ean } \pm \text { S.E. }\end{array}$} \\
\hline & & Mated & Pregnant on day $10^{\text {th }}$ & & \\
\hline Control & Vehicle & 5 & 5 & 0 & $9.30 \pm 0.47$ \\
\hline S. xanthocar pum seed & 50 & 5 & 4 & 20 & $4.33 \pm 0.66$ \\
\hline S. xanthocar pum seed & 100 & 5 & 0 & 100 & Nil \\
\hline S. xanthocar pum seed & 150 & 5 & 0 & 100 & Nil \\
\hline
\end{tabular}



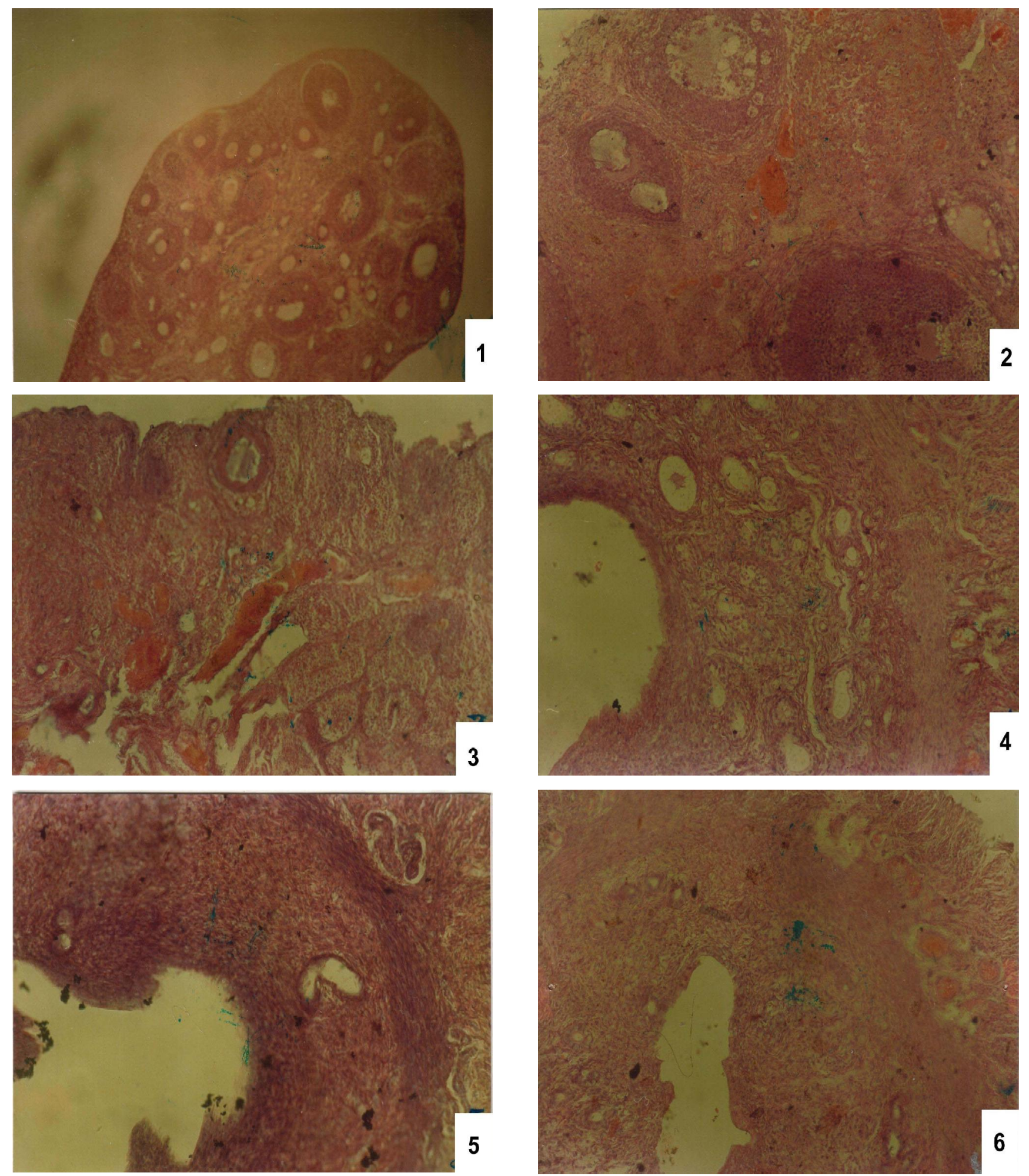

Figs. 1-6. Showing effects of Solanum xanthocarpum on ovary and uter us at different doses for 30 days of administration. (1) T.S. of $O$ vary of control albino rats with normal histo-architecture, all kinds of follicles, stroma and vascularity. X 100. (2) T.S. of ovary of treated al bino rats with $S$. xanthocar pum $100 \mathrm{mg} / \mathrm{kg} /$ day for 30 days. Note the arrest of follicle development and degeneration of other parts. X 200. (3) T.S. of ovary of treated albino rats with S. xanthocarpum $150 \mathrm{mg} / \mathrm{kg} / \mathrm{day}$ for 30 days. Note increased follicular atretia and total arrest of follicle development X200. (4) T.S. of uterus of controlled albino rats with normal histoarchitecture, normal endometrium, columnar epithelium, loose stroma, vascularity and uterine glands. X 200. (5) T.S. of uter us of treated albino rats with S. xanthocar pum $100 \mathrm{mg} / \mathrm{kg} /$ day for 30 days. Note histopathological changes in endometrium uter ine gland and vascularity. X 200. (6) T.S. of uterus of treated al bino rats with S. xanthocarpum $150 \mathrm{mg} / \mathrm{kg} / \mathrm{day}$ for 30 days. Note the atrophy of uter ine glands, reeduced endometrium and loss of vascularity. X 200. 
similar effect of the drug-Arjuna. Pathania et al. (2000) observed histological changes in ovary and uterus including oestrus cycle.

Bhardwaj and Mathur (1979) presented the results of an antifertility studies of Cassia fistula Linn. Fruit extracts on oestrus cycle, uterus and implantation. The higher doses showed encouraging activity which can be corroborated with the present study, Agarwal et al. (1980) found similar activity in fruits of J uniperus communis which resulted in $100 \%$ anti implantation at a dose of 500 $\mathrm{mg} / \mathrm{kg}$ in female albino rats. Padmashali et al. (2006) tested fruits of Balanites roxburghii (crude extract) at doses of 300 and $600 \mathrm{mg} / \mathrm{kg}$ doses and found abortifacient. Similarly, Balamurugan et al. (2009) reported that S. officinarum L. (leaves) methanolic extract at a dose of $500 \mathrm{mg} / \mathrm{kg}$ for 21 days caused prevention of pregnancy. It is concluded that $S$. xanthocarpum seed powder inhibited the ovarian function, change the uterine structure and prevent the implantation, thus, control the fertility of female albino rats.

\section{ACKNOW LEDGEMENT}

This work was supported by U.G.C., New Delhi, No. F. 6 1(98) 2006 (MRP/ARCB).

\section{REFERENCES}

Agarwal, O.P., Bhardwaj, S. and Mathur, R. (1980). Antifertility effects of fruits of J uniperus communis. Planta Medica. (Supl.), 98-101.

Aswal, B.S.; Bhakuni, D.S.; Goel, A.K.; Kar, K.; Mehrotra, B.N. and Mukherjee, K. (1984). Screening of Indian plants for Biological activity. Part X. Indian J . Exp. Biol., 22 :312332.

Balamurugan, K., Kalaichelvan, V.K.. Anuradha, G., Madhana Gopal, K., Meganathan, M. and Manavalan, R. (2009). Antifertility activity of Methanolic extract of Saccharum officinarum Linn. (leaves) on female albino rats. Int. P harm. Tech. Res., 1(4) : 1621-1634.

Bhardwaj, S. and Mathur, R. (1979). Antifertility screening of fruits of Cassia fistula Linn. In female albino rats. Comp. Physiol. Ecol., 4 (4) 277 - 279.

Chaudhury. R.R. (1966). Plants with possible antifertility activity. Special report series No. 55, I.C.M.R., New Delhi.

Chakraborti, B. Chaudhary, A. and Chaudhury, R.R. (1968). Antifertility effect of green leaves of Artobotrys odoratissimus. J. Indian M ed. Asso., 31 (5): 227 - 229.

Dixit, V.P. (1977). Effect of Chronically administration of Malva viscus conzattii flower extract on the female genital tract of gerbil, Merionis hurrianae, Jerdon. Indian J . Exp. Biol., 15 (8): 1650-1652.

Dixit, V.P. and Gupta R.S. (1982). Antispermatogenitic/ antiandrogenic properties of solasodine obtained from Solanum xanthocarpum berries on the male genital tract of $\operatorname{dog}$ (canis familiries) a histophysiological approach. Intern. I. Androl., 4:1 - 8

Farnsworth, N.R., Bingel, A.S., Cordell, S.A., Crane, F.A. and Fong H.H.S. (1975). Potential value of plants as sources of new antifertility agents. 1. J. Pharma. Sci. U.S.A., 64 (4): 535 - 558.

Jain, C.M. and Bharathi, K. (2011). Critical Review of Scientific validity of indigenous female contraceptive drugs described in Ayurvedic literature. Indian J. Trad. Knowl., 10(4) : 678-681.

Kholkute, S.D. and Udupa, K.N. (1974). Antifertility properties of Hibiscus rosa sinensis Linn. J. Res. Indian M ed., 9 (4): 99 - 102.

Kholkute, S.D., Chatterjee, S. and Udupa, K.N. (1976). Effect of Hibiscus rosa sinensis Linn. on oestrus cycle and reproductive organs in rats. Indian J. Exp. Biol., 14 (11): $703-704$.

Lal, B. and Udupa, K.N. (1993) . A preliminary study of antifertility effect of an indigenous drug - Arjuna (Terminalia arjuna). J our. Res. Ayur. Siddha, 14(1): 165-169.

Munshi, S.R. and Rao, S.S. (1972). Antifertility activity of an indigenous plant preparation ROC 101. Effect on reproduction. Indian J. M ed. Res. 60: 1054 - 1060.

Padmashali, B.; Vaidya, V.P.; Vagdevi, H.M. and Satyanarayana, N.D. (2006). Antifertility efficacy of the plant Balanites roxburghii (Balanitaceae) in female rats. Indian J. Pharma. Sci ., 68(3) : 347-351.

Pathania, P.C.; Singh, S.P. and Bhatia, D.K. (2000). Effect of Lantana camara Linn. leaves on ovarian and uterine histology, oestrus cycle and ovulation in Albino rats. Indian J our. Env. Sci., 4(1) : 53-60.

Pokharkar, R.D.; Saraswat, R.K. and Sheetal Kotkar (2010). Survey of plants having antifertility activity from Western ghat area of Maharashtra state. J our. Herb Med. Toxicol., $4(2): 71-75$

Prakash, A.O. (1979). Effect of E mbelia ribes Burm. Extracts on the uterus of rat: a histological study. Probe, 18 (3): 178- 184. Rao, M.V. (1986). Effect of Solanum xanthocarpum seed extracts on reproductive organs of male rats. Bio Sci. Res. Bull., 2: 22 - 28

Rao, M.V. (1988). Effect of alcoholic extract of Solanum xanthocarpum seeds in adult male rats. Indian J . Exp. Biol., 26: 95 - 98 .

Sharma, R.K., Chopra, G., Gyan Bhushan and Munjal, K. (2003). Use of Indian medicinal plants for infertility regulation in mammal. J. Exp. Zool., 6(1): 57-74. 